\title{
Persepsi Orangtua dan Guru terhadap Pembelajaran Masa Pandemi COVID-19 pada Anak Speech Disorder Usia 8 Tahun di Madrasah Ibtidayah
}

\author{
Sulistyani Puteri Ramadhani ${ }^{1}$, Asep Supena ${ }^{2}$ \\ Universitas Trilogi, DKI Jakarta, Indonesia ${ }^{1}$ \\ Universitas Negeri Jakarta, DKI Jakarta,Indonesia ${ }^{2}$

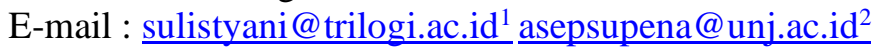

\begin{abstract}
Abstrak
Mengingat pembelajaran saat COVID-19 terus dilakukan diperlukannya orangtua, dan guru untuk bekerjasama dalam partisipasi anak yang memiliki ganguan berbicara dalam aktivitas keseharian. EA anak yang memiliki kebutuhan dengan gangguan berbicara bersekolah di Madrasah Ibtidayah Mishabul Falah Depok Jawa. EA memiliki kebutuhan pendidikan yang dijalankan seperti anak normal lainnya. Penting bagi guru dan orangtua dalam meningkatkan aktivitas saat COVID19. EA sebagai anak dengan kebutuhan khusus ganguan bicara selama COVID-19 menjadikan kegiatan aktifitas belajar yang dilakukan di lingkungan rumah. Penelitian ini memberikan deskripsi tentang pengalaman guru dan orangtua dalam pembelajaran saat COVID-19 dengan anak yang memiliki ganguan berbicara tetap belajar di lingkungan rumah. Penelitian ini menggambarkan kondisi sebenarnya yang dialami oleh guru dan orangtua EA dalam mengeksplor kegiatan aktivitas belajar saat COVID-19. Dengan menggunakan teknik triangulasi data yang didapatkan dari orangtua, guru dan pengamatan EA sebagai subjek penelitian. Data wawancara dan observasi dianalisis selama wabah COVID-19 secara sistematis dan terstruktur. Analisis data mengungkapkan empat tema : 1) cara guru dan orangtua dalam pembelajaran selama COVID-19 pada anak yang berkebutuhan khusus ganguan berbicara. 2) Hambatan orangtua dan guru menghadapi COVID-19 pada anak dengan ganguan berbicara. 3) Persepsi orangtua dan guru untuk memberikan aktivitas belajar pada anak pada ganguan berbicara. 4) Dukungan apa yang dibutuhkan anak dengan ganguan berbicara saat COVID-19. Hasil penelitian ini diungkapkan positif oleh orangtua dan guru pendamping kelas pada area perkembangan anak dengan ganguan berbicara untuk melibatkan EA dalam kegiatan aktivitas belajar di lingkungan rumah.
\end{abstract}

Kata kunci : pembelajaran, COVID-19, speech disorder, sekolah dasar

\begin{abstract}
Given that learning during Covid-19 continues to be carried out, it is necessary for parents and teachers to cooperate in the participation of children who have speech problems in daily activities. EA children who have needs with speech problems attend school at Madrasah Ibtidayah Mishabul Falah, Depok, Java. EA has educational needs that are run like any other normal child. It is important for teachers and parents to increase their activities during covid-19. EA as a child with special needs for speech disorders during Covid-19 made learning activities carried out in the home environment. This study provides a description of the experiences of teachers and parents in learning during Covid-19 with children who have speech problems while learning in the home environment. This study describes the actual conditions experienced by teachers and parents of EA in exploring learning activities during covid-19. By using data triangulation techniques obtained from parents, teachers and observations of EA as research subjects. Interview and observation data were analyzed during the covid-19 outbreak in a systematic and structured manner. Data analysis reveals four themes: 1. The way teachers and parents learn during Covid-19 in children with special needs with speech disorders. 2. Barriers for parents and teachers to face covid-19 in children with speech problems. 3. Parents and teachers' perceptions to provide learning activities for children in speaking disorders. 4. What support do children with speech disorders need during covid-19. The results of this study were positively expressed by parents and class assisting teachers in the area of child development with speaking disorders to involve EA in learning activities in the home environment.
\end{abstract}

Keywords: learning, COVID-19, speech disorder, elementary school

Copyright (c) 2020 Sulistyani Puteri Ramadhani, Asep Supena

$\triangle$ Corresponding author

Address : Taman Makam Pahlawan No 1 Kalibata Jakarta Selatan

Email: : sulistyani@trilogi.ac.id

Phone : 081210339004

DOI: https://doi.org/10.31004/basicedu.v4i4.548 
1275 Persepsi Orangtua dan Guru terhadap Pembelajaran COVID-19 pada Anak Speech Disorder Usia 8 Tahun di Madrasah Ibtidayah - Sulistyani Puteri Ramadhani, Asep Supena

DOI: https://doi.org/10.31004/basicedu.v4i4.548

\section{PENDAHULUAN}

COVID-19 merupakan penyakit menular yang disebabkan oleh virus bernama SARS-COV2, atau seringkali disebut Virus Corona. Virus Corona sendiri merupakan keluarga virus yang sangat besar. Ada yang menginfeksi hewan, seperti kucing dan anjing, namun ada pula jenis Virus Corona yang menular ke manusia, seperti yang terjadi pada COVID-19. Sampai saat ini terdapat lebih dari 1,2 juta orang terinfeksi dan hampir 65 ribu orang meninggal dunia. Di Indonesia sendiri, ada lebih dari 2 ribu kasus ditemukan dan hampir 200 orang telah meninggal dunia (Medicine, 2020).

Seperti dibanyak negara di dunia, sebagai bagian dari konsekuensi pandemi COVID-19 lockdown, puluhan ribu sekolah di Indonesia ditutup pada Maret 2020 (Mirzon Daheri, Juliana, Deriwanto, 2020). Meskipun demikian sebagian sekolah mulai dibuka kembali dua bulan kemudian di bulan Mei, pembatasan yang meluas tetap di tempatnya, dan prediksi kapan penutupan akan berakhir sepenuhnya tampaknya hampir tidak mungkin saat ini. Akibatnya, guru menghadapi tantangan yang signifikan beradaptasi dengan pengajaran online, dan mempertahankan setidaknya komunikasi minimum dengan siswa dan mendukung pembelajaran dan pengembangan siswa. Namun, sejauh mana guru berhasil menguasai tantangan ini dan faktor mana yang paling banyak relevan tetap tidak diketahui.

Dengan meningkatnya jumlah kasus COVID-19 khususnya di wilayah Jakarta, Depok dan Bekasi. Selain itu, pemerintah menghimbau kepada masyarakat untuk tidak berkumpul di tempat umum kecuali memang dalam keadaan penting. Pada kenyataannya walaupun tetap tinggal dirumah untuk mencegah penyebaran penyakit ini menimbulkan sebuah tantangan, khususnya dalam pendidikan dengan anak berkebutuhan khusus seperti anak dengan ganguan berbicara.

Disinilah problem itu, tidak ada waktu lagi untuk mempelajari semuanya dengan bersamasama. COVID-19 datang dengan keadaan memaksa semuanya untuk tetap di rumah. Maka guru harus bisa menggunakan berbagai media yang familiar digunakan orangtua. Harapannya tidak mempersulit untuk orang tua dalam penggunaan media online tersebut (Mirzon Daheri, Juliana, Deriwanto, 2020). Media yang paling sering digunakan komunikasi guru dengan orangtua melalui Whatsapp dengan tujuan guru dapat memantau perkembangan siswa dengan gangguan berbicara.

Konsep gangguan berbicara sebagai gangguan-gangguan artikulasi suara bicara, kefasihan, atau suara (Rohmani Nur Indah, 2017). Gangguan artikulasi adalah produksi suara ucapan atipikal yang ditandai oleh substitusi, kelalaian, penambahan, atau distorsi yang dapat mengganggu kejelasan. Gangguan kelancaran adalah gangguan dalam aliran berbicara yang ditandai dengan atipikal rate, ritme, dan pengulangan dalam suara, suku kata, kata, dan frase. Ini mungkin disertai ketegangan yang berlebihan, perilaku pergulatan, dan tingkah laku sekunder. Gangguan suara ditandai dengan produksi yang tidak normal atau hilangnya vocal kualitas, nada, kenyaringan, resonansi, atau durasi, yang tidak sesuai untuk 
sebuah usia atau jenis kelamin individu (Kuder, 2003).

Anak dengan ganguan berbicara memiliki efek yang ditandai dengan ganguan interaksi sosial, terbatas dengan anak yang tidak memahami komunikasinya. Untuk memberikan stigma negatif ini, anak dengan berkebutuhan khusus dengan gangguan bicara meskipun tetap berada dirumah dapat diberikan kegiatan aktivitas belajar. Walaupun tidak datang ke sekolah karena lockdown dengan keadaan darurat COVID-19 anak dengan berkebutuhan khusus dengan ganguan bicara diberikan bimbingan dari rumah melalui guru dan orangtua (Kuder, 2003). Cara meningkatkan kemampuan berbicara anak dengan ganguan berbicara dalam praktik pendidikan khusus yang meliputi aktivitas belajar dan berkomunikasi dalam kehidupan sehari-hari saat COVID-19.

Dampak dari terjadinya COVID-19 ini adanya penutupan sekolah dengan keadaan darurat COVID-19 menyebabkan anak-anak dengan penyakit khusus kebutuhan seperti ganguan berbicara dan keluarganya untuk dialami masalah pendidikan yang serius. Oleh karena itu, anak-anak dengan ganguan berbicara kehilangan proses pembelajaran di sekolah seperti : terapi fisik, terapi wicara, kegiatan fisik dan kurangnya komunikasi dengan teman di sekolah (Macauley \& Gutierrez, 2004). Anak yang miliki ganguan berbicara dengan karakteristik utamanya yaitu (interaksi sosial, komunikasi dan pola perilaku terbatas) yang mempengaruhi kualitas mereka kehidupan. Hal ini diantisipasi agar dapat membuat anak dengan ganguan berbicara rentan mengalami kesulitan dalam krisis COVID-19.

Namun, wabah COVID 19 juga menyebabkan perubahan rutinitas sehari-hari anakanak dengan anak ganguan bicara. Proses ini, yang juga sulit bagi individu dengan tipikal kreatifitas komunikasi dengan teman menjadi terhambat, dan sayangnya telah menyebabkan lebih banyak kesulitan-kesulitan untuk individu dengan anak kondisi ganguan bicara (Arnold, Winckel, \& Wyke, 2005). Anak dengan ganguan berbicara sangat bergantung pada rutinitas dan sangat bergantung kepada guru pendamping dan juga orangtua dalam pembelajaran. Rutinitas peka terhadap perubahan lingkungan. Perubahan ini dalam rutinitas keseharian anak dengan ganguan berbicara karena wabah COVID-19 mengungkapkan risiko yang dapat memengaruhi mereka dari perspektif yang berbeda dari kemungkinan risiko terhadap kesehatan fisik, kualitas hidup dan kesehatan mental dan untuk tetap tenang karena tidak banyak bergerak kehidupan dan aktivitas fisik yang rendah selama wabah COVID-19.

Aktivitas belajar dan berkomunikasi yang didefinisikan sebagai setiap gerakan bicara yang dihasilkan oleh otot mulut itu membutuhkan pengeluaran energi (Moriarty \& Gillon, 2006). Partisipasi dalam aktivitas fisik gerakan dan ucapan perlu dilatih dalam berkomunikasi sehingga dapat memberikan angka keuntungan bagi anak-anak dengan gangguan berbicara dalam hal kesehatan fisik dan mental (Landis, Vander Woude, \& Jongsma, 2004). 
1277 Persepsi Orangtua dan Guru terhadap Pembelajaran COVID-19 pada Anak Speech Disorder Usia 8 Tahun di Madrasah Ibtidayah - Sulistyani Puteri Ramadhani, Asep Supena

DOI: https://doi.org/10.31004/basicedu.v4i4.548

Studi yang meneliti fisik aktivitas pada anak-anak dengan dengan ganguan berbicara mengungkapkan bahwa kegiatan terapi wicara dengan menggunakan dapat memiliki efek positif pada kegiatan meniup, ataupun gerakan lokomotor dari organ mulut (Kirk, Gallagher, Coleman, \& Anastasiow, 2009). Keterampilan lokomotor dan kebugaran terkait keterampilan anak-anak dengan gangguan berbicara. Selain itu, penelitian telah menyarankan bahwa kegiatan fisik dapat membantu meningkatkan kepercayaan diri selfefficacy pada anak-anak dengan gangguan berbicara (Botting \& Adams, 2005).

Partisipasi dalam aktivitas fisik juga dapat berkontribusi untuk mengurangi tingkat stres dan kecemasan individu dengan anak gangguan berbicara (Ullrich, Ullrich, \& Marten, 2014). Mengenai karakteristik dasarnya dari anak-anak dengan gangguan berbicara, partisipasi dalam aktivitas fisik dapat meningkatkan perilaku sosial dan keterampilan komunikasi anak dengan gangguan berbicara. Anak dengan gangguan berbicara membutuhkan stimulasi diri yang datang dari lingkungannya, sehingga anak dengan gangguan berbicara dapat dikembangkan keterampilan komunikasinya. Banyak manfaat kesehatan dan sosial dari aktivitas fisik teratur, anak-anak dengan gangguan berbicara dikatakan memiliki tingkat aktivitas fisik yang lebih sedikit dari biasanya mengembangkan komunikasi dengan guru dan rekan teman di lingkungan tempat tinggal. Telah disarankan bahwa ada banyak kemungkinan hambatan pada anak-anak dengan gangguan berbicara yang menyebabkan kurangnya aktivitas fisik sehingga akan memperlambat perkembangan komunikasinya.

Menjelaskan hambatan yang terjadi pada anak gangguan bicara menyebabkan berkurangnya aktivitas fisik. Beberapa penelitian berfokus pada keterampilan motorik di bawah optimal dan kebugaran (fleksibilitas sendi, keseimbangan, kecepatan, perilaku fisik dan gangguan komunikasi, yang merupakan ciri khas membangun struktur komunikasi dari gangguan berbicara. Hal yang dilaporkan oleh orangtua saat memeriksa ke dokter tumbuh kembang memberikan gambaran terkait EA menderita gangguan bicara dikarenakan ada kelainan alat motor pada bagian mulut dan juga gangguan kecil yang diakibatkan dari rumah siput pada bagian telinga dalam. Beberapa studi menarik perhatian pada hambatan yang dilaporkan oleh orang tua (kebutuhan anak untuk pengawasan, waktu orang tua pembatasan, masalah perilaku). Mengingat orang tua adalah salah satu faktor utama untuk anak-anak untuk berpartisipasi dalam aktivitas fisik. Peneliti menekankan pentingnya orang tua mengetahui fisik nilai-nilai aktivitas, pengetahuan dan preferensi untuk memberikan pengalaman aktivitas fisik yang lebih baik kepada anak dengan gangguan berbicara (Langlois, Tucker, Sawatzky, Reed, \& Boliek, 2020).

Partisipasi anak dengan gangguan berbicara dari perspektif orangtua telah dilakukan di tidak adanya wabah atau kondisi abnormal sudah kesulitan untuk memahami bahasa anak. Namun, dalam beberapa hari terakhir, wabah COVID-19 telah menyebar muncul sebagai penghalang yang mungkin untuk anak-anak dengan gangguan 
1278 Persepsi Orangtua dan Guru terhadap Pembelajaran COVID-19 pada Anak Speech Disorder Usia 8 Tahun di Madrasah Ibtidayah - Sulistyani Puteri Ramadhani, Asep Supena

DOI: https://doi.org/10.31004/basicedu.v4i4.548

berbicara yang dapat menyebabkan kurangnya aktivitas fisik dan berbahasa. Anak-anak dengan gangguan berbicara menghadapi risiko tingkat aktivitas fisik yang rendah karena gaya hidup yang tidak banyak bergerak, tidak dapat memahami sosialnya, pusat pelatihan tertutup dan seringkali lingkungan belajar online yang tidak tepat selama krisis COVID-19. Meski masih baru subjek, tidak ada penelitian yang membahas pengetahuan, kebutuhan dan rekomendasi aktivitas fisik dengan komunikasi untuk pengalaman aktivitas fisik anakanak dengan anak gangguan berbicara selama wabah COVID-19.

Mempertimbangkan keadaan seperti ini dalam literasi tujuan dari studi kualitatif ini adalah untuk mengeksplorasi persepsi guru pembimbing dan orang tua tentang aktivitas belajar dan komunikasi untuk anak mereka dengan kondisi anak ganguan berbicara yang mengakibatkan kurang paham komunikasi anak dengan orangtua. Wawancara yang difokuskan dengan orang tua dan guru, adakah strategi guru untuk membantu anak dengan kebutuhan tentang faktor-faktor yang meningkatkan atau menurunkan pengalaman aktivitas belajar khususnya ngaji dari anak-anak dengan gangguan berbicara selama COVID-19. Penelitian ini bertujuan untuk menjawab hal-hal berikut pertanyaan penelitian: 1) bagaimana cara guru dan orangtua dalam pembelajaran selama COVID-19 pada anak yang berkebutuhan khusus gangguan berbicara? 2) hambatan orangtua dan guru menghadapi COVID-19 pada anak dengan ganguan berbicara? 3) bagaimana persepsi orangtua dan guru untuk memberikan aktivitas belajar pada anak pada gangguan berbicara? 4) dukungan apa yang dibutuhkan anak dengan ganguan berbicara saat COVID-19?

\section{METODE}

Pada penelitian ini metodologi yang digunakan yaitu deskriptif kualitatif. Pendekatan yang digunakan dalam penelitian ini adalah pendekatan kuantitatif. Penelitian deskriptif yaitu suatu metode penelitian yang ditujukan untuk menggambarkan fenomena-fenomena yang ada, yang berlangsung pada saat ini. Penelitian ini menggambarkan persepsi guru pendamping dan orangtua EA sebagai anak berkebutuhan khusus dengan ganguan berbicara di Madrasah Ibtidayiah Al-falah Sawangan Depok Jawa Barat.

Furchan mengemukakan yaitu dengan penelitian deskriptif memiliki mempunyai karakteristik dengan penelitian deskriptif cenderung menggambarkan suatu fenomena apa adanya dengan cara menelaah secara teratur-ketat, mengutamakan obyektivitas, dan dilakukan secara cermat. Tidak adanya perlakuan yang diberikan atau dikendalikan, dan tidak adanya uji $h$. (Furchan, 2004). Berdasarkan tulisan dari Sugiyono dikatakan bahwa, penelitian deskriptif mempunyai ciri-ciri yaitu tentang berhubungan dengan keadaan yang terjadi saat itu. Menguraikan satu variabel saja atau beberapa variabel namun diuraikan satu persatu. Variabel yang diteliti tidak dimanipulasi atau tidak ada perlakuan (treatment) (Sugiyono, 2014). Menurut Sinambela penelitian deskriptif adalah penelitian yang mendeskripsikan karakteristik tentang suatu fenomena yang diamati. Penelitian deskriptif salah satu jenis penelitian yang bertujuan untuk menyajikan gambaran yang 
1279 Persepsi Orangtua dan Guru terhadap Pembelajaran COVID-19 pada Anak Speech Disorder Usia 8 Tahun di Madrasah Ibtidayah - Sulistyani Puteri Ramadhani, Asep Supena

DOI: https://doi.org/10.31004/basicedu.v4i4.548

lengkap mengenai seting sosial (Lijan Poltak Sinambela, 2014).

Metode deskriptif (Syahrum, 2012) disebut mempunyai karakteristik: 1) penelitian deskriptif cenderung menggambarkan suatu fenomena apa adanya dengan cara menelaah secara teratur dan ketat dengan mengutamakan objektifitas, dilakukan dengan cermat. 2) Tidak ada perlakuan yang dilakukan. Penelitian deskriptif hanya mendeskripsikan suatu fenomena apa adanya, oleh karenanya dalam penelitian ini tidak ada perlakukan apapun. 3) Pengumpulan data dilakukan melalui teknik wawancara dengan menggunakan instrumen yang dipersiapkan atau dapat juga melalui pedoman wawancara.

Dalam hal ini peneltian yang akan dibahas bertujuan dalam mengeksplorasi dan mengklarifikasi mengenai suatu fenomena atau kenyataan sosial dengan jalan menggambarkan sejumlah variabel yang berhubungan dengan masalah dan variabel yang diamati. Dalam penelitian ini, akan mendeskripsikan : 1) cara guru dan orangtua dalam pembelajaran selama COVID19 pada anak yang berkebutuhan khusus ganguan berbicara; 2) Hambatan orangtua dan guru menghadapi COVID-19 pada anak dengan gangguan berbicara; 3) Bagaimana persepsi orangtua dan guru untuk memberikan aktivitas belajar pada anak pada ganguan berbicara; 4) Dukungan apa yang dibutuhkan anak dengan ganguan berbicara saat COVID-19.

Penelitian ini ditujukan kepada guru pendamping EA di sekolah, orangtua EA dan EA sebagai subjek penelitian yang akan diamati, diobservasi dan di wawancarai. Peneliti menggali informasi yang dibutuhkan sesuai dengan tema yang dibahas dan yang dibutuhkan. Pada dasarnya tujuan penelitian deskriptif yang digambarkan adalah dapat menghasilkan gambaran perspektif orangtua, guru pendamping terhadap siswa yang akurat tentang fenomena yang diteliti, menggambarkan proses yang terjadi, menyajikan berbagai informasi penting tentang variabel tersebut.

Penelitian ini mempertimbangkan keadaan COVID-19 untuk itu diperlukan dalam literasi tujuan dari studi kualitatif ini adalah untuk mengeksplorasi persepsi guru pembimbing dan orang tua tentang aktivitas belajar dan komunikasi untuk anak mereka dengan kondisi anak gangguan berbicara yang mengakibatkan kurang paham komunikasi anak dengan orangtua. Wawancara yang difokuskan dengan orang tua, guru dan anak EA. Topik yang dikaji dalam penelitian ini untuk mendeskripsikan bagaimana strategi guru untuk membantu anak dengan gangguan berbicara,

Dalam penelitian ini, metodologi deskriptif kualitatif adalah digunakan untuk meneliti persepsi orang tua tentang partisipasi anak dengan ganguan berbicara selama wabah COVID-19. Metodologi kualitatif deskriptif adalah interpretatif cara belajar yang menjadi dasar teliti pemahaman tentang suatu fenomena dan memberikan wawasan tentang perspektif dan pengalaman hidup peserta (Siyoto, 2015). Penelitian ini model deskripsi kualitiatif sering memberikan wawasan tentang bagaimana anak memahami dunia sosial dan itu bisa menjadi sumber daya yang berharga di daerah-daerah yang belum diteliti. Faktanya, mengingat itu berada di awal wabah COVID-19, itu terlihat bahwa tidak 
1280 Persepsi Orangtua dan Guru terhadap Pembelajaran COVID-19 pada Anak Speech Disorder Usia 8 Tahun di Madrasah Ibtidayah - Sulistyani Puteri Ramadhani, Asep Supena

DOI: https://doi.org/10.31004/basicedu.v4i4.548

ada cukup studi tentang anak-anak dengan gangguan berbicara dalam proses karantina.

Karena itu, memang demikian meramalkan bahwa penggunaan metode kualitatif deskriptif dapat berkontribusi pada persiapan konsep-konsep di bidang ini.

Sampel yang merupakan kunci utama dari penelitian deskriptif yang merupakan salah satu metode paling simpel untuk digunakan dalam menentukan dari beberapa kemungkinan subjek penelitian. Model pengambilan sampel kriteria termasuk seleksi peserta menurut kriteria yang telah ditetapkan sesuai dengan tujuan penelitian. Kriteria dalam studi ditentukan sebagai berikut: a) guru pendamping EA siap menerima berpartisipasi dalam penelitian secara sukarela, b) memiliki anak dengan ganguan berbicara yaitu orangtua dari EA, dan c) menerima untuk melakukan wawancara di telepon ataupun tatap muka.

Tujuan dan proses partisipasi studi oleh peneliti utama dijelaskan kepada orang tua EA melalui telepon dan Whatsapp. Kemudian, orangtua menyetujui jadwal yang sudah direncanakan dan kapan harus melakukan panggilan telepon sehingga diadakan dengan tatap muka. Mengingat peran guru dan orangtua yang cukup berimbang untuk yang menentukan dalam partisipasi anak EA pada proses pembelajaran saat COVID-19.

Pada dasarnya bagian ini menjelaskan bagaimana penelitian itu dilakukan. Materi pokok bagian ini adalah: (1) rancangan penelitian; (2) sampel (sasaran penelitian); (3) teknik pengumpulan data dan pengembangan instrumen; (4) dan teknik analisis data. Untuk penelitian yang menggunakan alat dan bahan, perlu dituliskan spesifikasi alat dan bahannya. Spesifikasi alat menggambarkan kecanggihan alat yang digunakan sedangkan spesifikasi bahan menggambarkan macam bahan yang digunakan.

Untuk penelitian kualitatif seperti penelitian seperti fenomenologi, studi kasus, dan lain-lain, perlu ditambahkan kehadiran peneliti, subyek penelitian, informan yang ikut membantu beserta cara-cara menggali data-data penelitian, lokasi dan lama penelitian serta uraian mengenai pengecekan keabsahan hasil penelitian. Pada penelitian ini nama anak di singkat EA kedalam bentuk penulisan untuk menghindarkan nama anak sebenarnya.

\section{HASIL DAN PEMBAHASAN}

Hasil wawancara dengan guru dan orangtua yang dikumpulkan sesuai dengan topik yang dibahas dengan analisis data yang dikumpulkan dari guru pendamping siswa, pada kegiatan guru yang dilakukan dari aktivitas belajar selama wabah COVID-19, hambatan aktivitas belajar selama wabah COVID-19, dan saran solusi untuk aktivitas fisik selama Wabah covid19. Dalam lingkup tema kemungkinan manfaat dari aktivitas selama belajar di rumah saat COVID-19, empat sub-tema diperoleh: strategi guru, kurikulum yang digunakan, hambatan yang dilalui oleh guru pendamping dan orangtua EA, aktivitas pendukung sebagai wawasan informasi yang dilakukan pada anak dengan gangguan berbicara.

Di bawah tema hambatan pembelajaran aktivitas selama wabah COVID-19, disana ada lima sub-tema: pendidikan jarak jauh yang kurang 
1281 Persepsi Orangtua dan Guru terhadap Pembelajaran COVID-19 pada Anak Speech Disorder Usia 8 Tahun di Madrasah Ibtidayah - Sulistyani Puteri Ramadhani, Asep Supena

DOI: https://doi.org/10.31004/basicedu.v4i4.548

memadai. Dalam tema saran untuk aktivitas fisik selama wabah COVID-19, tiga bagian dari subtema diidentifikasi: pendidikan keluarga, ahli dukungan dan dukungan sumber daya (buku penunjang,

\section{Topik 1 : Strategi Guru saat Aktivitas Anak dengan Gangguan Berbicara saat COVID-19}

Situasi pandemi COVID-19 telah menimbulkan tantangan yang belum pernah terjadi sebelumnya yang membutuhkan guru untuk beradaptasi dengan pengajaran online (Langlois et al., 2020). Dimulai bulan 2020 terlebih khusus di daerah Sawangan Depok Jawa Barat, sudah berzona merah. Pengajaran yang tadi di sekolah ditandai dengan siswa yang berkumpul di ruang kelas sesuai dengan mereka jadwal dan guru yang sering meliput konten standar mata pelajaran melalui pembelajaran dari rumah (thr, 2020). Situasi pembelajaran melalui daring saat COVID19 memang diperlukan kerjasama antara orangtua dan guru pendamping siswa khususnya bagi $\mathrm{AE}$ anak berkebutuhan khusus dengan gangguan berbicara. Perlunya strategi guru dan orangtua dalam melaksanakan pembelajaran daring untuk memberikan kebutuhan bagi anak dalam berbicara. Strategi yang dilakukan oleh guru ada beberapa kajian, yaitu melalui aplikasi Whatsapp dan Google Meet untuk pembelajaran saat COVID-19.

\section{Melalui Aplikasi Whatsapp}

Saat COVID-19 siswa khususnya anak berkebutuhan khusus dengan gangguan berbicara saat belajar. Strategi guru bersama orangtua diminta untuk mendengarkan voice notes tugas yang disampaikan oleh guru dengan Whatsapp, orangtua diminta ikut berperan. Guru juga memberikan materi dalam pembelajaran dengan cara mengirimkan video menggunakan bahasa non verbal sebagai tugas kemudian orangtua bersama siswa melakukan pembelajaran dari rumah. Siswa dan orangtua mengirimkan tugas yang disampaikan oleh guru dengan cara mengirimkan video, contohnya : siswa menyalin tulisan guru, orangtua bekerjasama dengan guru dalam menyukseskan pembelajaran. Orangtua dan guru memahami bahwa situasi saat COVID-19, itu terjadi di tengah proses yang lebih luas dalam sistem pendidikan. Digitalisasi di sekolah barubaru ini menjadi terkenal. Berkaitan dengan pembelajaran digital yang mengubah pembelajaran konvensional dan pengembangan siswa khususnya pada anak berkebutuhan khusus melakukan treatment pada anak yang dibutuhkan. Proses penugasan yang terjadi terkadang ada hambatan yang dilalui yaitu dengan keterbatasan gadget yang dimiliki orangtua sehingga dapat melakukan pembelajaran jika ayah ada dirumah yang dapat dilakukan pada malam hari dan hari libur.

\section{Melalui Aplikasi Google Meet}

Akibat dari pandemi COVID-19 memengaruhi hampir semua aspek masyarakat dan kehidupan sehari-hari, orang harus belajar mengatur komunikasi dan interaksi dengan cara baru. Peneliti mewawancarai bagaimana guru memulai awal beradaptasi dengan pengajaran online selama penutupan sekolah selama COVID19. Peneliti menanyakan bagaimana guru pendamping menguasai tantangan dalam situasi 
1282 Persepsi Orangtua dan Guru terhadap Pembelajaran COVID-19 pada Anak Speech Disorder Usia 8 Tahun di Madrasah Ibtidayah - Sulistyani Puteri Ramadhani, Asep Supena

DOI: https://doi.org/10.31004/basicedu.v4i4.548

yang tidak diketahui ini dan faktor apa yang dapat menjelaskan keberhasilan anak yang mengalami kebutuhan khusus gangguan berbicara dalam menguasai tantangan tersebut. Hampir semua guru di sekolah Madrasah Ibtidayah Mishabul Falah memberikan respon yaitu dengan memelihara komunikasi dengan siswa dan orang tua mereka. Mayoritas guru kelas ataupun guru pendamping memberikan respon untuk memperkenalkan pembelajaran baru secara visual konten selain memberikan tugas dan memberikan umpan balik kepada siswa mereka salah satunya menggunakan aplikasi Google Meet yang digunakan guru dan orangtua.

Namun, tantangan itu jelas membutuhkan integrasi jaringan internet yang terkadang menghambat terkendala signal, seperti pengajaran online dan penilaian online, dikuasai pada tingkat yang lebih rendah. Saat menganalisis faktor-faktor potensial yang mempengaruhi penguasaan tantangan tersebut. Guru pembimbing juga menjelaskan kesulitan dalam pelaksanaan jarak jauh selain orangtua yang perlu menambah wawasan dan juga jaringan signal yang dilakukan. Hasil wawancara dengan guru memberikan gambaran bahwa kompetensi guru perlu di update, signal perlu ada dan juga gedged perlu didukung. Saat menyampaikan pengajaran online lebih sering selama sekolah ditutup sementara terkadang menghadapi kendala. Secara khusus, pengajaran melalui Google Meet bisa dilakukan di waktu malam, dan pada hari libur ayah jika tidak membawa handphone. Dari sisi kemanjuan diri guru sangat penting untuk menyediakan referensireferensi digital yang diberikan untuk orangtua dan tugas siswa, tetapi juga untuk memberikan umpan balik kepada siswa. Ini temuan sesuai dengan penelitian yang menekankan pentingnya kompetensi guru dalam berhasil mencapai pembelajaran yang maksimal.

\section{Guru Berkunjung ke Rumah Siswa}

Guru memberikan kunjungan ke rumah anak dengan gangguan berbicara untuk melanjutkan proses pembelajaran saat COVID-19. Melihat kondisi dengan minimnya akses sinyal data seluler sehingga guru pembimbing dan orangtua mengalami keterlambatan belajar saat COVID-19 melalui pembelajaran jarak jauh. Guru pembimbing harus membuka kelas di rumah siswa dan mengunjungi siswa untuk dapat berinteraksi dengan siswa. Saat wawancara ini, guru berkata, jika dikatakan tidak sesuai protocol memang betul, namun seorang guru tidak dapat hanya menunggu dengan datangnya sarana dan prasarana yang memadai sesuai dengan keadaan, harus ada tindakan yang dilakukan yaitu guru melakukan kunjungan ke rumah siswa, sehingga adanya interaksi antara guru dan siswa beserta orangtua.

Hasil peneltian sebelumnya, juga dijelaskan bahwa kegiatan berkunjung kerumah, memberikan peluang bagi guru untuk mengetahui karakter siswa. Perlunya terwujud kerjasama antara orangtua dan guru sehingga terjalin dengan baik. Upaya hal ini perlu dilakukan oleh guru dalam rangka menciptakan suasana yang menyenangkan baik dengan orangtua dan siswa. Adanya komunikasi yang baik antara guru dan orangtua dapat menghindari kesalahpahaman dalam proses mengembangkan potensi anak baik di sekolah 
1283 Persepsi Orangtua dan Guru terhadap Pembelajaran COVID-19 pada Anak Speech Disorder Usia 8 Tahun di Madrasah Ibtidayah - Sulistyani Puteri Ramadhani, Asep Supena

DOI: https://doi.org/10.31004/basicedu.v4i4.548

maupun di rumah. Arah yang sama antara pendidikan yang ada di sekolah dengan pendidikan di rumah akan menciptakan nuansa yang harmonis bagi siswa sehingga mereka lebih mampu dalam mengembangkan potensi mereka (Amalia, 2016).

Sesuai dengan wawancara guru pendamping untuk memberikan kegiatan pembelajaran yang maksimal perlu adanya kunjungan ke rumah siswa. Bukan hanya dalam pembelajaran, namun adanya terapi wicara yang dilakukan oleh guru kepada siswa yang mengalami kesulitan bicara dengan menggunakan media yang diperlukan seperti kejelasan konsonan huruf, artikulasi dan komunikasi dengan menggunakan bahasa isyarat dengan non-verbal. Wawasan dari (Titles, Interest, Classroom, \& Development, 2012) dibutuhkan media pendukung kartu kartu bergambar sehingga memberikan pelajaran kosakata baru, dengan menggunakan metode yang menyenangkan bagi siswa berkebutuhan khusus dengan gangguan berbicara.

\section{Topik 2. Hambatan Orangtua dan Guru Menghadapi COVID-19 pada Anak Dengan Gangguan Berbicara}

Situasi COVID-19 memaksa orangtua dan guru pendamping untuk beradaptasi. Sekolah boleh tutup, tetapi proses belajar mengajar tetap berlanjut. Pembelajaran secara daring selama pandemi menjadi solusi bagi saat ini, namun tidak semudah yang dibayangkan. Banyaknya kendala yang dihadapi, baik para guru maupun orangtua terlebih khusus yang memiliki anak berkebutuhan khusus dengan gangguan berbicara.
Orangtua perlu beradaptasi pemindahan belajar mengajar dari sekolah ke rumah, mau tak mau peran orang tua cukup menentukan. Menjadi guru pendamping dadakan. Orang tua menjadi garda terdepan membimbing anak dalam proses belajar selama pandemi. Hasil wawancara dengan orangtua yatu menemui banyak kendala dalam pelaksanaannya. Dari tidak memiliki ponsel hingga tidak ada uang membeli kouta internet. Bahkan lebih parah lagi, ada orang tua yang tidak menguasai penggunakan teknologi komunikasi. Ini tentunya akan menjadi hambatan besar dalam proses belajar mengajar secara daring. Selama pembelajaran daring, dia terpaksa harus merogoh kocek banyak untuk membeli ponsel untuk anaknya.

Belum lagi ponsel harus berbagi dan dipergunakan secara bergiliran, karena dia punya dua anak yang sama-sama harus belajar daring. Sedangkan telepon pintar miliknya hanya ada satu unit. Kendala yang dihadapi bukan saja keterbatasan biaya. Supaya anaknya dapat melanjutkan belajar secara daring, terpaksa harus membeli telepon pintar secara kredit sebanyak dua unit. Belum lagi setiap hari harus membeli paket internet, agar dapat tersambung saat proses belajar daring. Tentunya semakin menambah beban pengeluaran keluarga.

Peneltian sebelumnya juga menjelaskan hambatan bagi orangtua dan guru yaitu : 1) penerapan pembelajaran daring secara masal di Indonesia ini masih tergolong hal baru, sehingga terkesan pemerintah dan dunia pendidikan belum siap dengan sistem ini; 2) masih kurangnya penguasaan teknologi dari pihak sekolah dan guru- 
1284 Persepsi Orangtua dan Guru terhadap Pembelajaran COVID-19 pada Anak Speech Disorder Usia 8 Tahun di Madrasah Ibtidayah - Sulistyani Puteri Ramadhani, Asep Supena

DOI: https://doi.org/10.31004/basicedu.v4i4.548

guru; 3) permasalahan sinyal internet yang tidak terjangkau ke seluruh negeri dengan merata; 4) sinyal televisi kabel belum merata di daerahdaerah terpencil (Mardhianto, 2020).

Wawancara dari guru pembimbing anak berkebutuhan khusus dengan gangguan berbicara, yaitu juga mengalami hambatan dengan signal dan juga pembelian paket data. Jika menggunakan Google Meet perlu memerlukan paket data internet yang jumlah bandwithnya banyak, sehingga kesulitan dalam membaginya. Hasil dari wawancara guru bukan hanya itu saja melainkan adanya hambatan dari jadwal orangtua yang tidak menentu karena terhambat dari penggunaan gadged itu, orangtua disekolah ini pendapatannya menengah kebawah sehingga ponsel yang dimiliki keluarga hanya satu padahal anaknya tiga. Belum lagi saat penyampaian materi pada anak, tidak ada interaksinya dengan siswa, sehingga guru tidak puas dalam kondisi pembelajaran daring saat COVID-19. Siswa yang diajarkan juga tidak memahami sepenuhnya kegiatan aktifitas yang akan dilakukan. Hasil wawancara dengan guru menggambarkan "Saat awal pandemi COVID-19 proses pembelajaran ini, saya berdiskusi dengan orangtua siswa yaitu orangtua kesulitan dalam menangani anaknya, karena latar pendidikan orangtua juga mempengaruhi proses pembelajaran dirumah."

Terlebih khusus dalam aktifitas pembelajaran fisik, sangat sulit menerapkan hal ini, karena orangtua yang belum memahami apa yang perlu dilakukannya. Contohnya saat pembelajaran ngaji, siswa EA sangat kesulitan dalam mengucap kata, sehingga memang dibutuhkan kesabaran guru untuk membantu siswa yang dengan kebutuhan khusus ini. Harapan dari guru pendamping adanya pendampingan orangtua dan guru untuk sama sama meningkatkan kegiatan siswa kedalam hal yang positif.

Dalam wawancara juga menyebutkan yaitu kurikulum K-13 yang digunakan di sekolah anak dengan kondisi gangguan berkomunikasi sangat kesulitan dalam memahami kegiatan pembelajaran. Kurikulum sekolah harus ditingkatkan terjalin dengan teknologi sehingga siswa dan orangtua diberi kesempatan untuk menggunakan lanjutan alat teknologi dan sumber daya digital untuk pemecahan masalah yang kreatif dan inovatif. Kondisi yang berbeda ketika menangani anak berkebutuhan khusus dengan ganguan berbicara yang dihadapi oleh EA. EA sangat membutuhkan perhatian karena masih tahap awal di kelas II, butuh pendampingan khusus untuk memantapkan diri agar lebih paham terhadap materi pembelajaran. Saat pembelajaran aktivitas guru merasa tidak efisien jika yang digunakan daring, sehingga guru kesulitan untuk terapi anak dengan kebutuhan gangguan berbicara.

\section{Tema 3: Persepsi Orangtua dan Guru untuk Memberikan Aktivitas Belajar saat COVID-19 pada Anak Pada Ganguan Berbicara}

Selama COVID-19 berlangsung manfaat dari aktivitas fisik selama wabah COVID-19 juga dirasakan oleh orangtua dan guru. Para orang tua menyatakan bahwa anak-anak mereka dengan gangguan berbicara sangat senang mengikuti aktivitas fisik ketika guru datang visit ke rumah siswa, untuk melakukan terapi, permainan dan 
1285 Persepsi Orangtua dan Guru terhadap Pembelajaran COVID-19 pada Anak Speech Disorder Usia 8 Tahun di Madrasah Ibtidayah - Sulistyani Puteri Ramadhani, Asep Supena

DOI: https://doi.org/10.31004/basicedu.v4i4.548

olahraga. Anak EA sangat berpartisipasi dengan penuh semangat terutama dalam aktivitas fisik luar ruangan (lingkungan taman, dll). Namun, orangtua menyatakan bahwa mereka menghadapi beberapa masalah yaitu ketika anak tidak mood untuk belajar, sehingga dibutuhkan guru yang dapat membingnya. Orang tua mengatakan bahwa anak yang mengalami gangguan berbicara tidak nyaman dengan situasi ini, mereka sesekali tanyakan kapan mereka akan berpartisipasi secara sosial dengan teman-teman di sekolah dengan melakukan kegiatan fisik, dan bahwa dalam gambar mereka, mereka menyertakan hal-hal yang mencerminkan keinginan mereka untuk berpartisipasi secara aktivitas fisik.

Dimulai dari di lingkungan rumah, situasi ini dianggap mencerminkan preferensi aktivitas fisik anak dengan gangguan berbicara yang harus tinggal di rumah karena wabah COVID-19. Orangtua melaporkan opini positif tentang manfaat potensial aktivitas fisik, terutama kesehatan, sosial dan psiko- aspek logis. Oleh karena itu, tema ini mencakup manfaat cocok diberikan oleh aktivitas fisik kepada anak-anak dengan ganguan berbicara selama wabah COVID-19.

\section{Kesehatan}

Dalam penelitian ini melalui wawancara, orang tua EA yang mengungkapkan pendapatnya tentang kontribusi aktivitas fisik terhadap aspek kesehatan anak-anak dengan gangguan berbicara secara khusus. Pendapat dari orang tua umumnya menyatakan bahwa aktivitas fisik akan berkontribusi kepada anak-anak mereka dengan gangguan berbicara untuk tetap bergerak melakukan olah tubuh supaya tubuh tetap sehat.

\section{Sosial}

Dalam penelitian terdahulu, orang tua dari ganguan berbicara menyatakan bahwa aktivitas fisik memberikan penghargaan yang signifikan terhadap keterampilan sosial anak-anak (Fox, Dodd, \& Howard, 2002). Dinyatakan juga bahwa anak dengan ganguan berbicara yang juga menunjukkan kekurangan besar dalam keterampilan sosial selain dari proses karantina, menunjukkan lebih banyak fitur asosial dengan proses ini. Ditemukan bahwa kecemasan umum yang orang tua miliki terhadap anak-anaknya adalah anak-anak dapat kembali bersosialisasi setelah karantina dengan melakukan proses komunikasi (South et al., 2020). Orang tua menyatakan bahwa aktivitas fisik memiliki sifat peran penting dalam menghilangkankecemasan tersebut. Dulu menyatakan bahwa melalui aktivitas fisik, keluarga dan anak untuk tetap interaksi menjadi lebih efisien, anak-anak lebih banyak patuh, aturan rumah lebih dipatuhi dan kontribusi positif dibuat untuk pembangunan sosial-anak dengan gangguan berbicara suka peningkatan kualitas waktu (Benaroya, Wesley, Ogilvie, Klein, \& Clarke, 1979). Orangtua yang berpendapat demikian berkonsultasi menekankan hubungan antara dokter kegiatan EA dan pengembangan keterampilan sosial. Contoh pendapat orang tua EA adalah sebagai berikut: "salah satu hal yang paling saya tahu adalah aktivitas fisik itu sangat baik untuk anak saya, dan saat-saat dia 
1286 Persepsi Orangtua dan Guru terhadap Pembelajaran COVID-19 pada Anak Speech Disorder Usia 8 Tahun di Madrasah Ibtidayah - Sulistyani Puteri Ramadhani, Asep Supena

DOI: https://doi.org/10.31004/basicedu.v4i4.548

berkomunikasi yang terbaik bagi saya adalah saatsaat kita bermain."

Selama wawancara, orang tua menyatakan bahwa mereka anak-anak hanya dapat berinteraksi secara online dengan keluarga mereka dan kerabat selama masa karantina. Namun, orang tua $\mathrm{AE}$ menyatakan bahwa mereka memiliki kesempatan untuk berinteraksi dengan banyak karakter dengan dunia virtual yang dibuat oleh aktivitas fisik. Pendapat orang tua tentang ini situasinya adalah sebagai berikut: "Guru memberikan video senam dasar untuk anak sekolah dasar. Orangtua bersama anak bahkan mempelajari senam tersebut. Dalam proses ini, situasi ini membuat kita lega. Bahkan untuk sementara, anak menjadi mendapat perhatiannya."

\section{Tema 4: Dukungan untuk Anak Berkebutuhan Khusus dengan Gangguan Berbicara}

Selama wawancara dengan guru dan orang tua, ada beberapa cara untuk mendukung anak dengan berkebutuhan khusus dengan gangguan berbicara untuk meningkatkan aktivitas fisik anakanak dalam proses karantina. Dalam lingkup tema ini, tiga sub-tema diidentifikasi: Pendidikan keluarga kation, dukungan ahli dan dukungan sumber daya seperti buku referensi bagi orangtua.

\section{Peran Keluarga}

Selama wawancara, orang tua EA menyatakan bahwa mereka ingin menerima pendidikan oleh dari anak berkebutuhan khusus dengan masalah gangguan berbicara lebih diprioritaskan selama proses karantina. Itu ditentukan secara khusus orang tua yang memiliki anak berkebutuhan khusus seperti ganguan berbicara ingin belajar bagaimana berperilaku dalam proses aplikasi sebagai serta mendapatkan pengetahuan tentang aktivitas belajar dengan berkomunikasi. (Burrus \& Haynes, 2009). Keluarga, yang menjalani gaya hidup terisolasi di proses karantina berpikir bahwa mereka dapat mengatasi proses ini lebih mudah dengan pelatihan yang akan diadakan (Perkins, 2010). Orang tua EA yang menganjurkan menyatakan bahwa pendidikan keluarga dapat dilakukan dengan mudah saluran nasional dan internet mengungkapkan pendapatnya tentang masalah ini sebagai berikut: "Saya pikir itu mestinya tidak terlalu sulit, jika kita harus memiliki aktivitas belajar anak dengan fisik untuk anak-anak kita tanpa meninggalkan rumah, maka ada banyak saluran dan internet untuk ini. Baik keluarga dan anak-anak akan melakukannya lebih maximal jika melatih anak kita dengan baik".

\section{Dukungan ahli}

Para orang tua berpikir bahwa mereka dapat membuat banyak kesalahan menonton video sendiri, kemudian diaplikasikan. Orangtua perlu edukasi dari guru pendamping, sebagai wawasan. Guru sebagai garda terdepan dalam pendidikan memiliki tugas untuk mengajar, mendidik, memberikan arahan serta bimbingan, melatih, memberikan penilaian dan evaluasi hingga memberikan dukunngan moral dan mental kepada peserta didik. Proses belajar mengajar yang dilaksanakan oleh guru dan peserta didik biasanya (Hilna Putria, Luthfi Hamdani Maula, 2020) Orangtua berpendapat bahwa diperlukan dukungan 
1287 Persepsi Orangtua dan Guru terhadap Pembelajaran COVID-19 pada Anak Speech Disorder Usia 8 Tahun di Madrasah Ibtidayah - Sulistyani Puteri Ramadhani, Asep Supena

DOI: https://doi.org/10.31004/basicedu.v4i4.548

ahli dalam aktivitas fisik dan terapy bagi anak nya. (Puspita, Perbawani, Adriyanti, \& Sumarlam, 2019). Bagi orangtua EA sangat berpengaruh sekali dengan dibantu dukungan ahli untuk meningkatkan lokomotor anak dapat berbicara dengan jelas, sampai saat ini EA diusia 8 tahun masih proses terapi, memang orangtua telat dalam memahami anak.

\section{Dukungan lingkungan}

Orang tua menyatakan bahwa dengan dimulainya wabah terkait proses karantina di negara lain. Guru pendamping khususnya yang menangani anak berkebutuhan khusus harus memulai persiapan sumber daya untuk siswanya. Dinyatakan bahwa salah satu sumber tersebut harus tentang aktivitas fisik yang secara langsung berkontribusi untuk semua bidang perkembangan anak dengan gangguan berbicara (Feit, 2007). Pendapat orang tua dari EA yang berpendapat bahwa sumber daya itu terkait aktivitas fisik untuk anak berkebutuhan khusus kebutuhan tetap di latar belakang karena :

"Mungkin bisa melihat wabah COVID-19 ini di negara lain dan memulai persiapan sumber daya, tetapi kesehatan melebihi dan persiapan seperti itu tidak dapat dilakukan untuk mencegah meninggal.

Dalam semua element dikatakan bahwa anak-anak harus melakukannya aktivitas fisik dan juga tetap melakukan pembelajaran walaupun ada keterbatasan."

Mempertimbangkan temuan yang diperoleh menurut pendapat orang tua, ditentukan bahwa setelah wabah COVID-19, anak dengan gangguan berbicara mengeluarkan uang lebih banyak seperti membeli kuota, mencari signal dan juga banyak waktu di rumah, mereka dapat melakukan lebih sedikit aktivitas belajar dan terapi sederhana dari kegiatan fisik seperti dikupas ke waktu normal, tingkat ketidakaktifan mereka meningkat, minat mereka pada perangkat teknologi telah meningkat, dan anak cenderung bosan ketika tidak ada kegiatan aktivitas yang dilakukan. Oleh karena itu, orang tua menyatakan bahwa pengembangan Aspek sosial anak-anak mereka terpengaruh secara negatif dalam proses karantina yang terjadi setelah wabah COVID-19 ini, karena tidak dibiasakan kembali dalam bersosial. Orang tua menetapkan itu dengan penambahan proses karantina ke situasi yang mencegah partisipasi dalam aktivitas fisik masalah yang berbeda dari sisi anak yang berkebutuhan khusus.

\section{SIMPULAN}

Penelitian ini sebagai referensi untuk penelitian selanjutnya yang berkaitan dengan anak berkebutuhan khusus di usia 8 tahun sekolah dasar yang meneliti persepsi dari orang tua dan guru pada pembelajaran saat COVID-19 yang memiliki anak dengan gangguan berbicara di Madrasah Ibtidayah Sawanga, Depok Jawa Barat. Proses pembelajaran karena wabah COVID-19 sangat penting yang dimana orangtua dan guru pendamping saling bersinergi dalam memberikan pembelajaran yang maksimal untuk dilakukan kepada anak dengan berkebutuhan khusus selama proses karantina akan berlanjut, studi ini akan memberikan kontribusi yang signifikan untuk pemahaman bagaimana aktivitas belajar dan gerakan fisik dirasakan di antara guru pendamping 
1288 Persepsi Orangtua dan Guru terhadap Pembelajaran COVID-19 pada Anak Speech Disorder Usia 8 Tahun di Madrasah Ibtidayah - Sulistyani Puteri Ramadhani, Asep Supena

DOI: https://doi.org/10.31004/basicedu.v4i4.548

dan orang tua yang memiliki anak dengan ganguan berbicara.

Dalam wawancara yang dilakukan di penelitian, ditentukan bahwa orang tua yang memiliki anak dengan ganguan berbicara memiliki kesadaran akan efek positif terhadap aktivitas kegiatan dan mereka berusaha untuk meningkatkan tingkat aktivitas belajar dan kegiatan fisik dengan memberikan stimulus komunikasi dengan anakanak mereka. Sebagai tambahan dari pendapat orang tua menunjukkan bahwa aktivitas fisik menyediakan manfaat yang signifikan bagi anakanak dengan ganguan berbicara selama proses karantina. Namun, dalam wawancara dengan orang tua, temuan terkait faktor-faktor yang mencegah mereka anak-anak dengan gangguan berbicara dari berpartisipasi dalam aktivitas belajar untuk tercapai.

Berdasarkan temuan yang diperoleh dalam penelitian ini, hasil penelitian dalam proses normal digunakan. Meskipun proses karantina telah menciptakan topik yang berbeda daerah sendiri, dianggap bahwa evaluasi menjadi dibuat sesuai dengan hasil penelitian di bawah dari kondisi normal. Selain itu, dalam penelitian yang dilakukan untuk kontribusi yang mungkin dari aktivitas belajar ke tingkat perkembangan anakanak dengan anak ganguan berbicara untuk dimasukkan dalam rangka proses karantina menurut pendapat orang tua, dan guru pendapat ini dibandingkan dengan temuan waktu normal. Bagian ini dibuat menggunakan tema yang dicapai sebagai hasil dari wawancara dengan orang tua dan guru pendamping EA.
Dalam penelitian yang telah dilakukan, sebagai subjek langsung yaitu orang tua EA yang memiliki anak berkebutuhan khusus dengan gangguan berbicara, guru pendamping EA di sekolah dan observasi dari EA yang membutuhkan penanganan khusus, menyatakan bahwa aktivitas pembelajaran dan gerakan fisik harus dilakukan dilakukan selama wabah COVID-19 mungkin memiliki efek positif pada bidang perkembangan anak dengan gangguan berbicara. Orang tua juga menyebutkan pentingnya aktivitas fisik, terutama dalam mengontrol berat badan dan mengurangi risiko obesitas. Menimbang bahwa sedentari gaya hidup telah meningkat dalam proses karantina, itu tidak mengherankan jika orang tua mengutarakan pendapat ini.

Dalam penelitian ini, penting untuk diperlukan peran dari guru pendamping sebagai wawasan orang tua menyatakan bahwa melakukan aktivitas belajar ataupun berkomunikasi dengan anak ganguan berbicara yang dilakukan dengan memahami bahasa isyarat anak yang dilakukan dalam proses karantina dapat berkontribusi untuk perkembangan sosial dan psikologis mereka. Tindakan isolasi sosial telah dilakukan diambil sesuai dengan proses karantina karena wabah COVID-19. Dalam konteks ini, hanya ada interaksi antara anggota keluarga di rumah lingkungan, dan hubungan dengan teman dibuat melalui aplikasi berbasis internet.

Anak dengan kebutuhan khusus ganguan berbicara dapat dijelaskan dengan peningkatan dan interaksi keluarga yang lebih kuat dan peningkatan kepatuhan menguasai aturan rumah melalui aktivitas belajar dengan bermain ataupun kegiatan 
fisik. Wabah COVID-19 telah memanfaatkan internet perangkat elektronik sangat umum di sekitar dunia. Sebagai akibat dari isolasi sosial, semua kebutuhan, terutama belanja sebelumnya, telah bertemu di Internet. Dalam proses karantina, selain kebutuhan dasar yaitu dengan cara bermain.

\section{UCAPAN TERIMA KASIH}

Ucapan terimakasih diberikan kepada Orangtua dari AE yaitu Teteh Wa yang telah memberikan informasi selangkapnya dalam penelitian yang telah dilakukan. Terimakasih kepada guru pendamping Ibu Sartika sebagai informan dalam penelitian ini. Terlebih khusus kepada ananda RN semoga senantiasa sehat selalu diberikan keberkahan hidup. Amin.

\section{DAFTAR PUSTAKA}

Amalia, H. (2016). Implementasi Home Visit Dalam Upaya Meningkatkan Pembelajaran

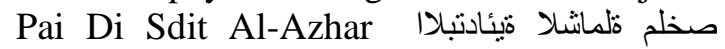

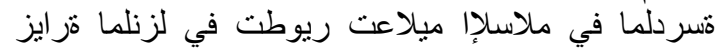

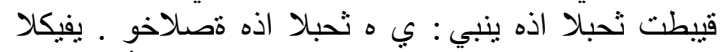

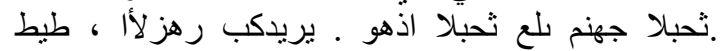
Didaktika Religia, 4(1), 77-106.

Arnold, E. G. E., Winckel, F., \& Wyke, B. D. (2005). J . A . M . M rtin Language in the Child: New York: Springer Verlag Wien NewYork.

Benaroya, S., Wesley, S., Ogilvie, H., Klein, L. S., \& Clarke, E. (1979). Sign language and multisensory input training of children with communication and related developmental disorders: Phase II. Journal of Autism and Developmental Disorders, 9(2), 219-220. https://doi.org/10.1007/BF01531535

Botting, N., \& Adams, C. (2005). Semantic and inferencing abilities in children with communication disorders. International Journal of Language and Communication Disorders, $\quad 40(1), \quad 49-66$. https://doi.org/10.1080/13682820410001723 390

Burrus, A., \& Haynes, W. (2009). Professional Communication in Speech-Language Pathology.

Feit, D. (2007). Language Problems. NewYork: Mc Graw Hill.

Fox, A. V., Dodd, B., \& Howard, D. (2002). Risk factors for speech disorders in children. International Journal of Language and Communication Disorders, 37(2), 117-131. https://doi.org/10.1080/13682820110116776

Furchan, A. (2004). Pengantar Penelitian dalam Pendidikan. Yogyakarta: Pustaka Pelajar Offset.

Hilna Putria, Luthfi Hamdani Maula, D. A. U. (2020). Hilna Putria, Luthfi Hamdani Maula, Din Azwar Uswatun, 4(4), 861-872. https://doi.org/10.31004/basicedu.v4i4.460

Kirk, S., Gallagher, J. J., Coleman, M. R., \& Anastasiow, N. (2009). Children Who Are Deaf or Hard of Hearing. Educating Exeptional Children.

Kuder, S. J. (2003). Teaching students with language and communication difficulties.

Landis, K., Vander Woude, J., \& Jongsma, A. E. (2004). The speech-language pathology treatment planner. Retrieved from https://books.google.com.cy/books/about/The _Speech_Language_Pathology_Treatment.ht $\mathrm{ml}$ ? id=Jt5pAAAAMAAJ\&redir_esc $=\mathrm{y}$

Langlois, C., Tucker, B. V., Sawatzky, A. N., Reed, A., \& Boliek, C. A. (2020). Effects of an intensive voice treatment on articulatory function and speech intelligibility in children with motor speech disorders: A phase one study. Journal of Communication Disorders, 86(April), 106003. https://doi.org/10.1016/j.jcomdis.2020.10600 3

Lijan Poltak Sinambela. (2014). Metodologi Penelitian Kualitatif. Yogyakarta: Graha Ilmu.

Macauley, B. L., \& Gutierrez, K. M. (2004). The 
1290 Persepsi Orangtua dan Guru terhadap Pembelajaran COVID-19 pada Anak Speech Disorder Usia 8 Tahun di Madrasah Ibtidayah - Sulistyani Puteri Ramadhani, Asep Supena

DOI: https://doi.org/10.31004/basicedu.v4i4.548

Effectiveness of Hippotherapy for Children With Language-Learning Disabilities. Communication Disorders Quarterly, 25(4), $205-217$.

https://doi.org/10.1177/15257401040250040 501

Mardhianto, K. (2020). Sekolah Minggu Masa Pandemi Covid 19: Didaché:Journal of Christian Education, 1(1), 13-24. https://doi.org/10.46445/djce.v1i1.291

Medicine, C. F. T. (2020). Buku Saku Desa Tangguh Covid-19. Jogjakarta: Universitas Gajah Mada.

Mirzon Daheri, Juliana, Deriwanto, A. D. A. (2020). Jurnal basicedu. Jurnal Basicedu, $3(2)$, 524-532. https://doi.org/10.31004/basicedu.v4i4.445

Moriarty, B. C., \& Gillon, G. T. (2006). Phonological awareness intervention for children with childhood apraxia of speech. International Journal of Language and Communication Disorders, 41(6), 713-734. https://doi.org/10.1080/13682820600623960

Perkins, M. R. (2010). Pragmatic Impairment. The Handbook of Language and Speech Disorders, (March 2010), 227-246. https://doi.org/10.1002/9781444318975.ch10

Puspita, A. C., Perbawani, A. A., Adriyanti, N. D., \& Sumarlam. (2019). Analisis Bahasa Lisan Pada Anak Keterlambatan Bicara, (21).

Rohmani Nur Indah. (2017). Gangguan Berbahasa: Kajian Pengantar. Uin-Maliki Press (Vol. 15).

Siyoto, S. (2015). Dasar Penelitian Metodologi. Sleman, Yogyakarta: Literasi Media Publishing.

South, K., McCulloch, L., McColl, B. W., Elkind, M., Allan, S. M., \& Smith, C. (2020). EXPRESS: Preceding Infection and Risk of Stroke: An Old Concept Revived by the COVID-19 Pandemic. International Journal of Stroke: Official Journal of the International Stroke Society, O(0), 1747493020943815. https://doi.org/10.1177/1747493020943815
Sugiyono. (2014). Metode Penelitian Pendidikan Pendekatan Kuantitatif, Kualitatif, dan R\&D. Bandung: Alfabeta.

Syahrum. (2012). Metodelogi Penelitian Kulitattif dan Kuantitatif. Bandung: Cita Pustaka Media.

thr. (2020). Pemkot Depok Tegaskan Belajar dari Rumah Sampai Akhir 2020. Retrieved from https://www.cnnindonesia.com/nasional/2020 0714103045-20-524382/pemkot-depoktegaskan-belajar-dari-rumah-sampai-akhir2020

Titles, R., Interest, O. F., Classroom, F. O. R., \& Development, P. (2012). RELATED TITLES OF INTEREST FOR CLASSROOM Articulatory and Phonological Impairments : A. Lloydia Cincinnati (Vol. In Press,). Retrieved from http://www.sciencedirect.com/science/article/ B6X4K-4X5JR7C1/2/8fb6ef1 18561f98f099c424b0b456d10

Ullrich, D., Ullrich, K., \& Marten, M. (2014). A longitudinal assessment of early childhood education with integrated speech therapy for children with significant language impairment in Germany. International Journal of Language and Communication Disorders, 49(5), 558-566. https://doi.org/10.1111/1460-6984.12092 